\title{
PENGARUH PENYULUHAN FILM DAN LEAFLET TERHADAP KEIKUTSERTAAN PEMERIKSAAN INSPEKSI VISUAL ASAM ASETAT (IVA) DI PUSKESMAS PASARWAJO
}

\author{
Eka Septiani \\ Kebidanan, Magister Kesehatan Masyarakat, STIKES Mandala Waluya, Septianieka27@mail.com
}

\begin{abstract}
INFO ARTIKEL
Riwayat Artikel:

Diterima: 15-08-2019

Disetujui: 25-11-2019

\section{Kata Kunci:}

Penyuluhan

Pemutaran film

WUS

Leaflet

Keikutsertaan

Pemeriksaan IVA

Abstrak: Di Indonesia, kanker serviks merupakan kasus terbanyak dan hampir 70\% ditemukan dalam kondisi stadium lanjut. Saat ini Indonesia menjadi negara dengan insiden kanker serviks tertinggi di Asia. Lebih dari 50 persennya meninggal dunia. Hal ini karena masih rendahnya pelaksanaan skrining, yaitu 1925.943 atau 5,1\%. Padahal, pelaksanaan skrining yang ideal adalah $80 \%$. Sebenarnya kanker serviks stadium awal bisa didiagnosa dengan melakukan pemeriksaan citologi melalui Inspeksi Visual Asam Asetat (IVA). Pemeriksaan IVA Positif 105.418 dan di curigai kanker leher rahim 3.601.Hampir 50\% penderita kanker serviks ternyata tidak melakukan IVA (Kementerian Kesehatan, 2017). Jenis penelitian ini adalah penelitian eksperimen, Populasi dalam penelitian ini adalah seluruh wanita pasangan usia Subur, di Puskesmas Pasarwajo yaitu kelurahan pasarwajo dan Kambumbulana. Jumlah wanita pasangan Usia subur tersebut secara berturut turut adalah 161 orang dan 90 orang. Jumlah sampel sebanyak 54 responden, dengan teknik pengambilan sampel proportional stratified random sampling. Data dikumpulkan menggunakan kuesioner kemudian dianalisis secara deskriptif dan inferensial menggunakan rumus Wilcoxon rank test dan uji mann-whitney. Hasil penelitian menunjukkan bahwa Penyuluhan film, leaflet, berpengaruh terhadap pengetahuan, sikap dan keikutsertaan pemeriksaan tentang pemeriksaan IVA di Puskesmas Pasarwajo serta penyuluhan film lebih efektif di banding leafleat dalam meningkatkan pengetahuan, mengubah sikap dan keikutsertaan pemeriksaan dalam pemeriksaan IVA di Puskesmas Pasarwajo. Perlu diadakannya penyuluhan kesehatan tentang deteksi dini kanker serviks dengan memanfaatkan penyuluhan film dengan kepada masyarakat terutama remaja perempuan agar dapat melakukan sedini mungkin secara rutin dan teratur setiap jadwal yang ditentukan, sehingga diharapkan mampu mendeteksi dini kanker serviks.
\end{abstract}

\section{A. LATAR BELAKANG}

Kanker adalah pertumbuhan abnormal dari suatu sel atau jaringan dimana sel atau jaringan tersebut tumbuh dan berkembang tidak terkendali. Kecepatan tumbuhnya berlebihan dan sering disertai perubahan

\begin{abstract}
In Indonesia, cervical cancer is the most cases and almost $70 \%$ are found in advanced stage conditions. Indonesia is currently the country with the highest incidence of cervical cancer in Asia. More than 50 percent died. This is due to the low implementation of screening, i.e. 1,925,943 or 5.1\%. In fact, the ideal screening implementation is $80 \%$. Early cervical cancers can be diagnosed by conducting a cytological examination through the visual inspection with acetic acid (VIA). The VIA positive 105,418 and in the suspect cancer of the cervix 3.601. Nearly 50\% of patients with cervical cancer did not perform a visual inspection with acetic acid (Ministry of Health, 2017). This type of research is experimental research; the population in this study is all women of the fertile age couple, in Pasarwajo Puskesmas village Pasarwajo and Kambumbulana. The number of women couples in the fertile age is 161 people and 90 people. Large samples of 54 respondents, sampling techniques using proportional stratified random sampling. Data collected using questionnaires were subsequently analyzed descriptively and inferential using the Wilcoxon rank test and Mann-Whitney test formula. The results showed that film counseling, leaflets, influence the knowledge, attitudes, and participation of examinations on the examination of the VIA inspection in Pasarwajo Puskesmas and film counseling are more effective in the appeal Leaflet in enhancing the knowledge, changing attitudes and the participation of examinations in the examination of the VIA at Puskesmas Pasarwajo. Need health counseling about cervical cancer early detection by utilizing film counseling with the community especially young women to do as early as possible regularly and regularly each scheduled schedule, So it is expected to be able to detect early cervical cancer.
\end{abstract}

peran sel yang akhirnya mengganggu organ lain. (KeMenKes, 2016).

Sebenarnya kanker serviks stadium awal bisa didiagnosa dengan melakukan pemeriksaan citologi melalui Inspeksi Visual Asam Asetat (IVA). Pemeriksaan Inspeksi Visual Asam Asetat ( IVA ) Positif 105.418 dan 
di curigai kanker leher rahim 3.601.Hampir 50\% penderita kanker serviks ternyata tidak melakukan Inspeksi Visual Asam Asetat (Kementerian Kesehatan, 2017).

Deteksi dini kanker serviks yang dikenal umum adalah Pap Smear, yang biasanya dilakukan di rumah sakit di bagian laboratorium. Namun, ada pula cara alternatif yakni metode Inspeksi Visual Asam Asetat (IVA). Inspeksi Visual Asam Asetat (IVA) merupakan pemeriksaan dengan cara mengamati secara inspekulom serviks yang di mana kapas telah dipulas dengan asam asetat atau asam cuka (3-5\%) selama 1 menit. Daerah yang tidak normal akan berubah warna dengan batas tegas yang menjadi putih (acetowhite), yang mengindikasikan bahwa serviks mungkin memiliki lesi pra kanker.

Promosi Kesehatan merupakan upaya untuk meningkatkan pengetahuan masyarakat yang berfokus pada aspek pencegahan. Promosi Kesehatan WUS tentang kanker serviks, etiologi, tanda dan gejala, penatalaksanaan, faktor risiko, dan pencegahan diharapkan dapat mempengaruhi cara berpikir wanita pasangan usia subur terhadap kanker serviks agar menjadi lebih waspada.

\section{B. METODE PENELITIAN}

Metode penelitian yang digunakan adalah eksperimen. Populasi dalam penelitian ini adalah seluruh wanita pasangan usia subur, di Puskesmas Pasarwajo yaitu kelurahan Pasarwajo dan Kambumbulana. Jumlah wanita pasangan usia subur tersebut secara berturut turut adalah 161 orang dan 90 orang. Jumlah sampel sebanyak 54 responden, di mana teknik pengambilan sampel menggunakan proportional stratified random sampling. Data diperoleh menggunakan kuesioner kemudian dianalisis secara deskriptif dan inferensial menggunakan rumus Wilcoxon rank test dan uji mann-whitney.

\section{HASIL DAN PEMBAHASAN}

\section{ANALISIS}

Penelitian ini dilaksanakan di Puskesmas Pasarwajomulai bulan Mei sampai bulan Juli tahun 2019. Sampel terbagi dalam Dua kelompok yaitu dua kelompok intervensi penyuluhan film dan leaflet. Jumlah sampel sebanyak 54 orang yang terdiri atas 35 orang untuk kelompok satu dan 19 orang untuk kelompok dua.

Data yang telah dikumpulkan diolah melalui proses editing, coding, tabulating, dan selanjutnya dianalisis menggunakan program SPSS. Hasil analisis data ditampilkan dalam bentuk tabel dan grafik disertai interpretasi.

\section{Karakteristik Responden}

a. Umur

Umur adalah usia responden dari lahir sampai pada usia terakhir. Adapun distribusi responden menurut kelompok umur di lokasi intervensi yaitu kelurahan Pasarwajo dan keluran Kambulambulana dapat dilihat pada tabel 1 .

TABEL 1

Distribusi frekuensi dan persentase responden berdasarkan umur pada kelompok film dan leaflet

\begin{tabular}{ccc}
\hline \multirow{2}{*}{ Kelompok Umur } & \multicolumn{2}{c}{ Jumlah } \\
\cline { 2 - 3 } & $\mathrm{n}$ & $\%$ \\
\hline $22-25$ & 4 & $7 \%$ \\
$26-29$ & 4 & $7 \%$ \\
$30-33$ & 9 & $17 \%$ \\
$34-37$ & 14 & $26 \%$ \\
$38-41$ & 10 & $19 \%$ \\
$42-45$ & 13 & $24 \%$ \\
Jumlah & 54 & $100 \%$ \\
\hline
\end{tabular}

b. Tingkat Pendidikan

Tingkat pendidikan adalah suatu kondisi jenjang pendidikan yang dimiliki oleh seseorang melalui pendidikan formal yang dipakai oleh pemerintah serta disahkan oleh departemen pendidikan. Adapun tingkat pendidikan responden dalam penelitian ini dapat dilihat pada tabel 2 .

TABEL 2

Distribusi frekuensi dan persentase responden berdasarkan pendidikan pada kelompok film dan leaflet

\begin{tabular}{ccc}
\hline \multirow{2}{*}{ Pendidikan } & \multicolumn{2}{c}{ Jumlah } \\
\cline { 2 - 3 } & $\mathrm{N}$ & $\%$ \\
\hline SD & 9 & $17 \%$ \\
SMP & 15 & $28 \%$ \\
SMA & 19 & $35 \%$ \\
DIII & 4 & $7 \%$ \\
S1 & 7 & $13 \%$ \\
Jumlah & 54 & $100 \%$ \\
\hline
\end{tabular}

\section{c. Pekerjaan}

Pekerjaan merupakan suatu kegiatan yang wajib dilakukan oleh responden demi kelansungan hidupnya atau untuk memenuhi sebagai macam kebutuhan hidupnya. Adapun jenis pekerjaan responden dalam penilitian ini dapat dilihat pada table 3 . 
TABEL 3 .

Distribusi frekuensi dan persentase responden berdasarkan Pekerjaan pada kelompok film dan leaflet

\begin{tabular}{ccc}
\hline \multirow{2}{*}{ Pekerjaan } & \multicolumn{2}{c}{ Jumlah } \\
\cline { 2 - 3 } & N & \% \\
\hline Ibu Rumah Tangga & 36 & $67 \%$ \\
Honorer & 7 & $13 \%$ \\
PNS & 5 & $9 \%$ \\
Swasta & 6 & $11 \%$ \\
Jumlah & 54 & $100 \%$ \\
\hline
\end{tabular}

2. Analisis Deskriptif

a. Pengetahuan

Pengetahuan sebelum dan sesudah di berikan intervensi Film dan Leaflet yaitu terjadi perubahan di kelurahan Pasarwajo dan kelurahan Kambulambulana di wilayah kerja puskesmas Pasarwajo dapat di lihat pada tabel 4.

TABEL 4.

Distribusi frekuensi perubahan pengetahuan pada tiap kelompok intervensi film dan leafleat

\begin{tabular}{|c|c|c|c|}
\hline \multicolumn{4}{|c|}{ Leafleat } \\
\hline Pengetahuan & $\mathbf{n}$ & Mean & $\begin{array}{c}P- \\
\text { Value }\end{array}$ \\
\hline $\begin{array}{c}\text { Pre }- \text { Test } \\
\text { Post-Test }\end{array}$ & 19 & $\begin{array}{l}61,32 \\
87,86\end{array}$ & 0,000 \\
\hline
\end{tabular}

b. Sikap

Sikap sebelum dan sesudah di berikan intervensi Film dan Leaflet yaitu terjadi perubahan di kelurahan Pasarwajo dan kelurahan Kambulambulana di wilayah kerja puskesmas Pasarwajo dapat di lihat pada tabel 5 .

TABEL 5.

Distribusi frekuensi perubahan sikap pada tiap kelompok intervensi film dan leaflet

\begin{tabular}{ccccc}
\hline \multirow{2}{*}{ Sikap } & \multicolumn{2}{c}{ Film } & \multicolumn{2}{c}{ Leafleat } \\
\cline { 2 - 5 } & $\begin{array}{c}\text { Pre- } \\
\text { Test }\end{array}$ & $\begin{array}{c}\text { Post- } \\
\text { Test }\end{array}$ & $\begin{array}{c}\text { Pre- } \\
\text { Test }\end{array}$ & $\begin{array}{c}\text { Post- } \\
\text { Test }\end{array}$ \\
\hline Kurang & 17 & 0 & 10 & o \\
Cukup & 18 & 3 & 9 & 6 \\
Baik & 0 & 32 & 0 & 13 \\
Jumlah & 35 & 35 & 19 & 19 \\
\hline
\end{tabular}

\section{c. Keikutsertaan}

Keikutsertaan Inspeksi Visual Asam Asetat (IVA) sebelum dan sesudah di berikan intervensi Film dan Leaflet yaitu terjadi perubahan di kelurahan Pasarwajo dan kelurahan Kambulambulana di wilayah kerja Puskesmas Pasarwajo dapat di lihat pada tabel 6.
TABEL 6.

Distribusi frekuensi perubahan keikutsertaan pada tiap kelompok intervensifilm dan leaflet

\begin{tabular}{ccccc}
\hline \multirow{3}{*}{ Keikutsertaan } & \multicolumn{2}{c}{ Film } & \multicolumn{2}{c}{ Leafleat } \\
\cline { 2 - 5 } & $\begin{array}{c}\text { Pre- } \\
\text { Test }\end{array}$ & $\begin{array}{c}\text { Post- } \\
\text { Test }\end{array}$ & $\begin{array}{c}\text { Pre- } \\
\text { Test }\end{array}$ & $\begin{array}{c}\text { Post- } \\
\text { Test }\end{array}$ \\
\hline Kurang & 35 & 14 & 19 & 15 \\
Cukup & O & O & o & o \\
Baik & O & 21 & O & 4 \\
Jumlah & 35 & 35 & 19 & 19 \\
\hline
\end{tabular}

\section{Analisis Inferensial}

a. Analisis Pengaruh Penyuluhan Film Terhadap Pengetahuan tentang pemeriksaan Inspesi Visual Asam Asetat (IV)di Kelurahan Pasarwajo dapat lihat pada tabel 7 .

TABEL 7.

Analisis pengaruh Kelompok Intervensi film pada pengetahuan

\begin{tabular}{cccc}
\hline \multicolumn{4}{c}{ Film } \\
\hline Pengetahuan & $\mathrm{n}$ & Mean & $\begin{array}{c}P \text { - } \\
\text { Value }\end{array}$ \\
\hline $\begin{array}{c}\text { Pre }- \text { Test } \\
\text { Post }- \text { Test }\end{array}$ & 35 & $\begin{array}{c}60,86 \\
91,43\end{array}$ & 0,000 \\
\hline
\end{tabular}

b. Analisis Pengaruh Leaflet Terhadap pengetahuan tentang pemeriksaan Inspeksi Visual Asam Asetat ( IVA ) di kelurahan Kambulambulana dapat lihat pada tabel 8 .

TABEL 8.

Analisis pengaruh Kelompok Intervensi leaflet pada pengetahuan

\begin{tabular}{ccccc}
\hline \multirow{2}{*}{ Pengetahuan } & \multicolumn{2}{c}{ Film } & \multicolumn{2}{c}{ Leaflet } \\
\cline { 2 - 5 } & $\begin{array}{c}\text { Pre- } \\
\text { Test }\end{array}$ & $\begin{array}{c}\text { Post- } \\
\text { Test }\end{array}$ & $\begin{array}{c}\text { Pre- } \\
\text { Test }\end{array}$ & $\begin{array}{c}\text { Post- } \\
\text { Test }\end{array}$ \\
\hline Kurang & 35 & o & 19 & o \\
Cukup & O & 3 & O & 5 \\
Baik & O & 32 & O & 14 \\
Jumlah & 35 & 35 & 19 & 19 \\
\hline
\end{tabular}

c. Analisis Pengaruh Penyuluhan Film Terhadap Sikap tentang pemeriksaan Inspesi Visual Asam Asetat ( IVA ) di kelurahan Pasarwajo dapat lihat pada tabel 9. 
TABEL 9

Analisis pengaruh Kelompok Intervensi film pada sikap

\begin{tabular}{cccc}
\hline \multicolumn{3}{c}{ Film } & \\
\hline Sikap & $\mathrm{n}$ & Mean & $\begin{array}{c}P \text { - } \\
\text { Value }\end{array}$ \\
\hline Pre-Test & & 53,29 & o,ooo \\
Post - Test & 35 & 80,86 & \\
\hline
\end{tabular}

a. Analisis Pengaruh Leaflet Terhadap Sikap Tentang Pemeriksaan Inspesi Visual Asam Asetat( IVA ) di Kelurahan Kambulambulana dapat lihat pada tabel 10.

TABEL 10

Analisis pengaruh Kelompok Intervensi leaflet pada sikap

\begin{tabular}{cccc}
\hline \multicolumn{4}{c}{ Leafleat } \\
\hline Sikap & $\mathrm{n}$ & Mean & P-Value \\
\hline Pre-Test & & 49,89 & \\
Post-Test & 19 & 76,63 & 0,000 \\
\hline
\end{tabular}

b. Analisis Pengaruh Penyuluhan Film Terhadap Keikutsertaan Tentang Pemeriksaan Inspesi Visual Asam Asetat(IVA) di Keluraha Pasarwajodapat lihat pada tabel 11.

TABEL 11

Analisis pengaruh Kelompok Intervensi film pada keikutsertaan

\begin{tabular}{cccc}
\hline \multicolumn{3}{c}{ Film } & \\
\hline Keikutsertaan & $\mathrm{n}$ & Mean & $\begin{array}{c}P- \\
\text { Value }\end{array}$ \\
\hline Pre - Test & & 50,00 & \\
Post - Test & 35 & 80,00 & 0,000 \\
\hline
\end{tabular}

c. Analisis Pengaruh Leaflet Terhadap Keikutsertaan tentang pemeriksaan Inspeksi Visual Asam Asetat( IVA ) dapat lihat pada tabel 12.

TABEL 12

Analisis pengaruh

Kelompok Intervensi leaflet pada keikutsertaan

\begin{tabular}{cccc}
\multicolumn{4}{c}{ keikutsertaan } \\
\hline Leafleat \\
Keikutsertaan & $\mathrm{n}$ & Mean & $\begin{array}{c}P \text { - } \\
\text { Value }\end{array}$ \\
\hline Pre-Test & & 50,00 & \\
Post - Test & 19 & 60,53 & 0,046 \\
\hline
\end{tabular}

d. Analisis Perbedaan Efektifitas Penyuluhan Film dan Leaflet Terhadap Pengetahuan tentang pemeriksaan Inspeksi Visual Asam Asetat (IVA ) di kelurahan Pasarwajo dan kelurahan Kambulambulana dapat lihat pada tabel 13.
TABEL 13

Analisis perbedaan efektifitas Kelompok Intervensi Film dan Leafletpada pengetahuan

\begin{tabular}{ccc}
\hline \multirow{3}{*}{ Pengetahuan } & $\begin{array}{c}\text { Pre Test Film } \\
\text { Vs Pre Test } \\
\text { Leafleat }\end{array}$ & $\begin{array}{c}\text { Post Test } \\
\text { Film Vs } \\
\text { Post Test } \\
\text { Leafleat }\end{array}$ \\
\hline$P$ & 1,000 & 0,032 \\
\hline
\end{tabular}

e. Analisis Perbedaan Efektifitas Penyuluhan Film dan Leaflet Terhadap Sikap Tentang Pemeriksaan Inspesi Visual Asam Asetat( IVA dapat lihat pada tabel 14 .

TABEL 14

Analisis perbedaan efektifitas Kelompok Intervensi Film dan Leafletpada sikap

\begin{tabular}{ccc}
\hline Sikap & Pre Test Film Vs & $\begin{array}{c}\text { Post Test } \\
\text { Film Vs } \\
\text { Post Test } \\
\text { Leafleat }\end{array}$ \\
\hline$P$ & 0,778 & 0,032 \\
\hline
\end{tabular}

f. Analisis Perbedaan Efektifitas Penyuluhan Filmdan Leaflet Terhadap Keikutsertaan Wanita Pasangan Usia Subur Dalam Pemeriksaan Inspesi Visual Asam Asetat ( IVA ) dapat dilihat pada table 15 .

TABEL 15

Analisis perbedaan efektifitas Kelompok Intervensi pada keikutsertaan.

\begin{tabular}{ccc}
\hline Keikutsertaan & $\begin{array}{c}\text { Pre Test Film Vs } \\
\text { Pre Test Leaflet }\end{array}$ & $\begin{array}{c}\text { Film Vs Post } \\
\text { Test Leaflet }\end{array}$ \\
\hline$P$ & 1,000 & 0,007 \\
\hline
\end{tabular}

D. TEMUAN DISKUSI

\section{Pengaruh Penyuluhan Film Terhadap Pengetahuan tentang pemeriksaan Inspeksi Visual Asam Asetat( IVA ).}

Penyuluhan film tentang kanker serviks bertujuan untuk menambah pengetahuan tentang kanker serviks, deteksi dini dan penanganya. diperuntukkan bagi wanita usia subur yang sudah menikah atau yang aktif secara seksual. Melalui penyuluhan media komunikasi yang bersifat audio visual atau film dengan penyampaian suatu pesan kepada sekelompok orang yang berkumpul di suatu tempat tertentu. Penyuluhan film diberikan pada saat ibu hamil dikumpulkan di suatu tempat kemudian diberikan potongan film pendek dengan durasi 10-15 menit mengenai Pemeriksaan Inspeksi Visual Asam Asetat (IVA) yang memuat pengertian, manfaat atau kegunaan pemeriksaan, cara pemeriksaan dan lain sebagainya. Hal ini terlihat dalam Pre-Test sebelum intervensi pada kelompok filmyang berpengetahuan kurang 35 orang hal ini dikarenakan hampir semua responden belum mendapatkan informasi yang jelas mengenai kanker seviks dan pendeteksianya, 
sehingga mendapat kategori kurang. Setelah ProTest Hasil penelitian mengalami meningkatan perubahan pengetahuan di banding dengan pengukuran awal ( pre-test ). Hal ini menunjukkan hasil uji dengan wilcoxon diperoleh $\mathrm{p}=0,000<0,05$ artinya terdapat pengaruh film terhadap pengetahuan tentang pemeriksaan Inspeksi Visual Asam ( IVA )dengan nilai rata-rata pada saat pre-test 60,86 dan pada saat post-test 91,43.Terjadinya peningkatan pengetahuan karena dari responden yang sudah mendapatkan informasi melalui penyuluhan Film yang telah di berikan atau interfensi yang telah dilakukan berdasarkan teori tentang pengetahuan terjadi perubahan karena seseorang telah melakukan pengindraan terhadap suatu objek yang di maksud di sini intervensi (Film ) yang telah diberikan.

\section{Pengaruh Leafleat Terhadap Pengetahuan tentang pemeriksaan Inspeksi Visual Asam Asetat ( IVA).}

Leaflet adalah suatu alat promosi atau pemasaran yang dicetak pada selembar kertas, yang umumnya mengunakan art paper atau art carton.Di dalam leaflet sendiri biasanya berisikan informasi singkat mengenai suatu programatau acara yang di tawarkan. Leaflet diberikan pada responden penelitian setelah responden penelitian dikumpulkan risalah satu rumah warga dan kemudian diberikanleflet tentang Pemeriksaan Inspeksu Visual Asam Asetat, di mana pada kegiata trsebut responden diberikankesempatan kepada peneliti apabila ada hal yang kurang dipahami kepada peneliti.

Hasil penelitian yang di lakukan pre-test dari 19 responden di dapatkan kategori kurang. Hal ini disebabkan hampir semua responden belum mendapatkan informasi yang jelas mengenai kanker seviks dan pendeteksianya. Setelah di lakukan posttest hasil penelitian menunjukkan bahwa pada pengukuran akhir semua responden mengalami peningkatan skor pengetahuan dibandingkan dengan pengukuran awal (pretest). menunjukkan hasil uji dengan wilcoxon diperoleh $\mathrm{p}=0,000<0,05$ artinya terdapat pengaruh leaflet terhadap pengetahuan tentang pemeriksaan Inspeksi Visual Asam Asetat pada wanita pasangan usia subur di wilayah kerja Puskesmas Pasarwajo, dengan nilai rata-rata pada saat pre-test 61,32 dan pada saat post-test 87,86 . Terjadinya peningkatan pengetahuan di karenakan responden telah mendapatkan intervensi ( Leaflet ) yang telah di berikan sehingga responden mengetahui tentang kanker serviks dan pendeteksianya hal ini juga telah sejalan dengan teori yang ada menjelaskan bahwa semakin tinggi tingkat pengetahuan maka semakin tinggi pula pemahaman seseorang.
Leaflet selain untuk kegiatan promosi, fungsi lain dari leaflet adalah sebagai alat untuk menyebarkan informasi akan suatu gerakan sehingga informasi dapat diketahui oleh banyak orang. Pengetahuan adalah mediator perubahan perilaku. Meskipun tak mutlak bahwa pengetahuan yang baik akan melahirkan perilaku yang baik pula. Namun pengetahuan merupakan hal yang sangat berpengaruh terjadinya sebuah perubahan perilaku ke arah yang lebih baik.

Hasil penelitian ini menunjukkan bahwa peningkatan skor pengetahuan mengalami perubahan yang bagus, hal tersebut menunjukkan bahwa dalam jangka waktu yang lebih lama dengan leaflet memiliki retensi pengetahuan yang lebih baik dibandingkan pada pertemuan sebelumnya. Hal ini dapat terjadi karena ada kedekatan yang terbangun baik antara fasilitator dan peserta Pada diskusi dengan leaflet ada juga pelibatan peran aktif peserta sepanjang proses intervensi.

Hasil penelitian ini sejalan dengan penelitian Windi Kusniah Chusniah ( 2016 ) yang berjudul Pengaruh Pendidikan Kesehatan Tentang IVA dan Paps Smear Terhadap Tingkat Pengetahuan dan Sikap WUS Melalui Media Leaflet Berkalender Dalam Upaya Deteksi Dini Kanker Serviks di wilayah Kerja Puskesmas Manahan Kota Surakarta di mana tingkat pendidikan seseorang mempengaruhi kemampuan untuk menerima informasi dan pengetahuan serta menerima perubahan. Menunjukkan bahwa terdapat peningkatan sebesar 6 point antar mean tingkat pengetahuan WUS tentang IVA dan Pap-smear sebelum dan setelah diberikan pendidikan kesehatan dengan metode ceramah + leaflet berkalender ( $p=0,0001)$ pada kelompok eksperimen. Hal ini berhubungan dengan kemampuan seseorang untuk mengambil keputusan berdasarkan pengetahuan yang dia peroleh.Tingkat pendidikan juga dihubungkan dengan tingkat sosial ekonomi keluarga.Tingkat pendidikan dan sosial ekonomi berhubungan dengan kemampuan keluarga dalam menggunakan fasilitas kesehatan untuk meningkatkan derajat kesehatan keluarga dan melakukan deteksi dini terhadap kondisi kesehatannya.

\section{Pengaruh Penyuluhan Film Terhadap Sikap tentang keikutsetaan pemeriksaan Ispeksi Visual Asam Asetat( IVA ).}

Media film membangun pengetahuan kita mengenai isu-isu sosial dan memiliki pengaruh signifikan terhadap bagaimana kita menyikapi masalah. Kita tidak dapat menyangkalbahwa media film memiliki kontribusi besar dalam membentuk cara berpikir kita. Jadi terlihat jelas bahwa media film juga memainkan peran penting dalam hal kita menyikapi hidup. 
Pendidikan kesehatan adalah proses membantu sesorang, dengan bertindak secara sendiri-sendiri ataupun secara kolektif, untuk membuat keputusan berdasarkan pengetahuan mengenai hal-hal yang memengaruhi kesehatan pribadinya, dan orang lain. Suatu pikiran kecenderungan dan perasaan seseorang untuk mengenal aspek-aspek tertentu pada lingkungan yang seringnya bersifat permanen karena sulit diubah. Komponen yang dimaksud adalah pengetahuan yang selama ini diperoleh semasa hidup, dimana sangat mempengaruhi perilaku saat bertindak. Pengertian lainnya menyebutkan bahwa sikap merupakan kecondongan evaluatif seseorang terhadap suatu subjek maupun objek. Sikap yang dimiliki setiap individu memberikan warna tersendiri untuk seseorang bertingkah laku.

Hasil Penilitian yang di lakukan Pre-test atau sebelum intervensi dari 35 responden di dapatkan kategori kurang 17 responden di karenakan karna masih kurangnya kesadaraan tentang pemeriksaan Inspeksi Visual Asam Asetat ( IVA ) dan 18 responden yang mendapaatkan kategori cukuphal ini di karenakan bersifat sementarakesiapan atau kesedian untuk bertindak.

Hasil Penelitian menunjukkan hasil uji dengan wilcoxon diperoleh $\mathrm{p}=0,000<0,05$ artinya terdapat pengaruh film terhadap sikap tentang pemeriksaan Inspeksi Visual Asam Asetat( IVA ) di wilayah kerja Puskesmas Pasarwajo, dengan nilai rata-rata pada saat pre-test 53,29 dan pada saat post-test 80,86 , hal ini di sebabkan sikap bisa berubah karena responden merespon dengan intervensi (film) yang telah di berikan sehingga terjadinya reaksi individual di dasarkan kesiapan atau kesediaan responden.

Sikap merupakan reaksi atau respon seseorang yang masih tertutup terhadap suatu stimulus atau obyek. Sikap dikatakan sebagai respon evaluative. Respon evaluative berarti bahwa bentuk reaksi yang dinyatakan sebagai sikap itu timbul didasarkan oleh proses evaluasi dalam diri individu yang memberi kesimpulan stimulus dalam bentuk nilai baik-buruk, positif-negatif, menyenangi-tidak menyenangkan sebagi potensi terhadap objek sikap(Sinaga and Ardayani, 2016).

Hasil penelitian ini sejalan dengan hasil penelitian Sri Muliyati (2015) yang berjudul Pengaruh media film terhadap sikap ibu pada deteksi dini kanker serviks bahwa menunjukan terdapat peningkatan pada sikap, niat dan keikutsertaan ibu pada tes Inspeksi Visual Asam Asetat. Hasil analisis menunjukan bahwa pemberian pendidikan kesehatan melalui film berpengaruh terhadap sikap ibu pada tes IVA. Setelah diberikan pendidikan kesehatan melalui film, median skor sikap responden meningkat dari 44,23 menjadi 78,85. Persentase peningkatan menunjukan terjadi peningkatan sebesar $78,27 \%$. Hasil uji statistik menunjukan terdapat perbedaan bermakna antara sebelum pemberian pendidikan kesehatan melalui film dan setelah pemberian pendidikan kesehatan melalui film $(\mathrm{P}<0,05)$. Berdasarkan hasil penelitian tersebut dapat diasumsikan bahwa pemberian pendidikan kesehatan melalui film berpengaruh secara signifikan terhadap sikap ibu pada tes IVA.

\section{Pengaruh Leafleat Terhadap Sikap tentang pemeriksaan Inspeksi Visual Asam Asetat( IVA ).}

Leaflet adalah salah satu bentuk publikasi singkat yang mana biasanya berbentuk selebaran yang berisi keterangan atau informasi tentang sebuah program, organisasi atau bentuk layanan lainnya yang perlu diketahui oleh khalayak umum. Dengan adanya media leafleat di harapkan dapat menambah pengetahuan serta Sikap yang di mana dalam hal ini sikap merupakan hal sangat penting berpengaruh dalam pengambilan keputusan seseorang. Oleh karena itu, informasi sangat berkepentingan dalam hal pengetahuan tentang bagaimana terbentuknya sikap itu dan bagaimana bisa mengubahnya supaya seseorang bersikap positif. Pada hasil penelitian PreTest dari 19 reponden yang mendapatkan kategori Kurang 10 orang dan 9 orang kategori cukup,hal ini di karenakan masih ada sikap yang belum ada karena di pengaruhi oleh beberapa faktor misalakan pengetahuanya dan lain lain.

Hasil Penelitian Menunjukkan dari hasil uji dengan wilcoxon diperoleh $\mathrm{p}=0,000<0,05$ artinya terdapat pengaruh leaflet terhadap sikap tentang pemeriksaan Inspeksi Visual Asam Asetat ( IVA ) di wilayah kerja Puskesmas Pasarwajo, dengan nilai rata-rata pada saat pre-test 49,89 dan pada saat posttest 76,63 , Hal ini di sebabkan karena pengetahuan yang sebelumnya di daptkan dari intervensi yang telah di lakukan sehingga menimbulkan kepercayaan atau keyakinan dalam pemeriksaan Inspeksi Visual Asam Aseta ( IVA ).

Sikap merupakan kecenderungan yang dipelajari untuk berperilaku dengan cara yang tetap menyenangkan atau tidak menyenangkan terhadap suatu obyek tertentu. Setiap unsur dalam definisi ini sangat penting untuk memahami mengapa dan bagaimana sikap terkait dalam perilaku seseorang. Situasi dalam berbagai peristiwa atau keadaan yang, pada tahap dan waktu tertentu, mempengaruhi hubungan antara sikap dan perilaku. Situasi tertentu dapat menyebabkan seseorang berperilaku dengan cara yang kelihatannya tidak konsisten dengan sikap mereka.

Hal ini sejalan dengan penelitian Windi Chusniah Rahmawati (2016) menunjukkan bahwa terdapat peningkatan sebesar 7 point antara mean sikap WUS tentang IVA dan Pap-smear sebelum dan setelah diberikan pendidikan kesehatan dengan 
metode ceramah + leaflet berkalender $(\mathrm{p}=0,0001)$. Tidak jauh berbeda dengan kelompok kontrol terdapat peningkatan sebesar 6 point antara mean sikap WUS terhadap IVA dan Pap-smear sebelum dan setelah diberikan pendidikan kesehatan dengan metode ceramah $(\mathrm{p}=0,0001)$. Berdasarkan uraian diatas terdapat perbedaan skor sikap WUS pada pretest dan post-test pendidikan kesehatan baik pada kelompok eksperimen maupun kelompok kontrol tentang IVA dan Papsmear dalam upaya deteksi dini kanker serviks.

\section{Pengaruh Penyuluhan Film Terhadap Keikutsertaan tentang pemeriksaan Inspeksi Visual Asam Asetat ( IVA ).}

Film merupakan salah satu media massa dari komunikasi massa, maka peran dan fungsi film sendiri sama dengan peran dan fungsi dari komunikasi massa, yaitu dapat digunakan sebagai sarana penyebaran informasi mengenai kejadiankejadian dalam lingkungan, baik diluar maupun di dalam masyarakat.Film juga cermin atau jendela masyarakat di mana media massa itu berada sehingga nilai, norma, dan gaya hidup yang berlaku pada masyarakat akan disajikan dalam film yang diproduksi. Akan tetapi film juga mempengaruhi sikap dengan cara memperteguh, menciptakan, danmengubah norma jika film tersebut ditonton berulangkali. Dalam hal ini, menonton film merupakan perilaku penggunaan media yang dapat dilihat dari frekuensi menonton film dan jenis film yang ditonton. Dari hasil penelitian Pre -test 35 responden didapatkan kategori kurang 35 responden sebelum dilakuan intervensi .Setelah di lakuakn Intervensi hasil penelitianmenunjukkan hasil uji dengan wilcoxon diperoleh $\mathrm{p}=0,000<0,05$ artinya terdapat pengaruh film terhadap keikutsertaan tentang pemeriksaan Inspeksi Visual Asam Asetat( IVA ) pada wanita pasangan usia subur di wilayah kerja Puskesmas Pasarwajo, dengan nilai rata-rata pada saat pre-test 50,00 dan pada saat post-test 80,0o, hal ini di karenakan pengaruh dari intervensi ( film ) yang telah di berikan sehingga menambah pengetahuan dan sikap dalam keikutsertaan Inspeksi Visual Asam Asetat ( IVA ).

Penyuluhan film bisa mempengaruhi siapa saja karena pada dasarnya dalam jiwa manusia ada manusia yang krisis dan cenderung untuk menerima semua sajian diberikan. Sehingga masyarakat merasa membutuhkan informasi yang dapat mempengaruhi perilaku dar yang mereka tonton.

Hasil Penelitian ini sejalan dengan penelitian Lia Karisma Saraswati (2009) yang berjudul Pengaruh Promosi Kesehatan Terhadap Pengetahuan Tentang Kaner Serviks dan Partisipasi Wanita dalam Deteksi Dini anker Serfiks, menunjukkan bahwa berdasarkan hasil penelitian di ketahui bahwa partisipasi responden baik pada kelompok penyuluhan dengan film secara deskritif menunjukan adanya peningkatan signifikan arna di pengaruhi peerubahan pengtahuan yang baik.

\section{Pengaruh Leafleat Terhadap Keikutsertaan Pemeriksaan Inspeksi Visual Asam Asetat ( IVA ).}

Keikutsetaan adalah partisipasi dalam proses pengindetifikasian masalah dan potensi yang ada di masyarakat, pemilihan dan pengambilan keputusan tentang alternatif solusi untuk menangani masalah, pelaksanaan upaya mengatasi masalah, dan keterlibatan seseorang dalam proses mengafaluasi perubahan yang terjadi. Dengan adanya media leaflet di harapkan dapat menambah pengetahuan serta Sikap dan disertai dengan keikutsertaan . Oleh karena itu, informasi sangat berkepentingan dalam hal pengetahuan tentang bagaimana terbentuknya sikap itu dan bagaimana bisa mengubahnya supaya seseorang bersikap positif. Dari penelitian yang telah di lakukan Pre-test dari 19 responden terdapat kategori kurang yaitu 19 responden sebelum di lakuakan intervensi.Setelah di lakukan intervensi (Leaflet) Hal ini Menunjukkan hasil uji dengan wilcoxon diperoleh $\mathrm{p}=0,000<0,05$ artinya terdapat pengaruh leafletterhadap keikutsertaan pemeriksaan Inspeksi Visual Asam Asetat( IVA ) pada wanita pasangan usia subur di wilayah kerja Puskesmas Pasarwajo, dengan nilai rata-rata pada saat pre-test 50,00 dan pada saat post-test 60,53terjadi perubahan dari intervensi yang telah diberikan sehingga mendapatkan pengetahuan dan adanya sikap serta keikutsertaan dalam pemeriksaan Inspeksi Visual Asam Asetat ( IVA ).

Keikusertaan seseorang dapat diartikan sebagai keterlibatan dan dalam suatu kegiatan tertentu baik secara lansung maupun tidak lansung dengan dipengaruhi oleh pengetahuan yang baik dan sikap sehingga terjadilah keterlibatan tersebut dimulai dari gagasan, perumusan, kebijaksanaan hingga pelaksanaan program.

Hasil Penelitian ini sejalan dengan penelitian Ayu Ulfah Nur Lubis ( 2015 ) yang berjudul Pengaruh media film dan leaflet terhadap pengetahuan tentang kanker serviks dan partisipasi wanita dalam detesi dini kanker serviks dikampung Darek kecamatan Padang Sidempuan selatan bahwa Pengaruh media leaflet terhadap partisipasi tentang kanker serviks dan diketahui bahwa terdapatpeningkatan rata-rata partisipasi sebelum diberikan media leaflet dengan sesudahdiberikan media leaflet yaitu 1,83 menjadi 3,77 dengannilai $\mathrm{p}=0,001(\mathrm{p}<0,05)$, maka dapat disimpulkanbahwa ada pengaruh media leaflet terhadap partisipasiresponden tentang pemeriksaan kanker serviks. 


\section{Perbedaan Efektifitas Penyuluhan Film dan Leafleat Terhadap Pengetahuan tentang keikutsertaan pemeriksaan Inspeksi Visual Asam Asetat ( IVA ).}

Efektivitas merupakan suatu pencapaian dari kegiatan sesuai dengan yang telah di rencanakan. Suatu pekerjaan yang telah di lakukan oleh seseorang tentu bisa menunjang untuk mencapai tujuan secara kelompok. Di samping itu, pencapaian tujuan kelompok akan mendukung pencapaian suatu tujuan secara keseluruhan.Dalam Efektifitas Penyuluhan Film dan Leafleat Terhadap Pengetahuan tentang keikutsertaan pemeriksaan Inspeksi Visual Asam Asetat( IVA ) dapat di lihat dari hasil penelitian menunjukkan bahwa penyuluhan Filmdan leaflet setara dalam meningkatkan Pengetahuan reponden tentang pemeriksaan Inspeksi Visual Asam Asetat( IVA ) sebelum di lakukan Intervensi.Oleh karena itu dapat disimpulkan bahwa media Filmdan leaflet memiliki efektivitas yang sama dalam Pengetahuan tentang pemeriksaan Inspeksi Visual Asam Asetat di puskesmas Pasarwajo. Hal ini dikarenakan dari kedua intervensi pada dua kelompok sama-sama belum mendapatkan informasi yang lebih jelas mengenai informasi kanker serviks dan pendeteksianya.

Penelitian ini menunjukkan hasil uji perbandingan keikutsertaan pada saat pre-test di kelompok penyuluhan film dan leafleat dengan menggunakan uji mann withney (U-Test) diperoleh $\mathrm{p}=1,000>0,05$ artinya tidak terdapat perbedaan pengetahuan pada kelompok penyuluhan film dan leafleat tentang pemeriksaan Inspesi Visual Asam Asetat pada wanita pasangan usia subur di wilayah kerja Puskesmas Pasarwajo pada saat sebelum dilakukan intervensi, sedangkan pada saat post-test diperoleh $\mathrm{p}=0,032<0,05$ artinya terdapat perbedaan pengetahuan pada kelompok penyuluhan film dan leaflet tentang pemeriksaan Inspeksi Visual Asam Asetat pada wanita pasangan usia subur di wilayah kerja Puskesmas Pasarwajo pada saat setelah dilakukan intervensi hal ini di sebabkan kedua intervensi yang di berikan mengalami perbedaan yang mempengaruhi pengetahuan artinya efektifitas film lebih baik mempengruhi pengetahuan yang di mana ada ketertarikan yang mudah menyerap informasi lewat film.

Koneksi dan pertukaran informasi ini dapat membantu seseorang mengembangkan kemampuan untuk menggali pengetahuan baru kapan saja. Salah satu transformasi pembelajaran yang luar biasa mengakui bahwa belajar bukanlah aktivitas individu, melainkan sebuah proses yang memungkinkan siswa untuk lebih berkembang. Hasil penelitian menyatakan bahwa film dan leaflet sebagai platform pembelajaran secara kelompok dapat meningkatkan aksesibilitas materi pembelajaran dan kinerja kegiatan pembelajaran (Ashiyan and Salehi, 2016).

Penelitian sebelumnya yang di lakukan oleh Moronikan Silalahi (2018) yang berjudul Efetififitas Audio Visual dan blooklet sebagai media edukasi untuk meningkatkan prilaku skrining IVA, Hasil penelitian menunjukkan perbedaan pengetahuan yang signifikan dengan nilai $\mathrm{p}<0.001$ sebelum dan setelah diberikan pendidikan kesehatan pretestposttest, pada kelompok intervensi dan kelompok kontrol.

Peningkatan rata-rata pengetahuan lebih besar pada kelompok intervensi dibandingkan kelompok kontrol. Hasil penelitian yang dilakukan oleh Compaore et al., tingkat pendidikan berpengaruh terhadap keikutsertaan wanita melakukan skrining untuk yang pertama kali.14 Pada penelitian ini dijelaskan bahwa tingkat pendidikan akan memberi pengaruh responden untuk lebih mengetahui suatu penyakit, dan dapat mengambil keputusan untuk melakukan skrining bahkan melakukan vaksinasi HPV untuk mereka sendiri dan untuk anak-anak mereka.

\section{Perbedaan Efetifitas Penyuluhan Film dan Leafleat Terhadap Sikap Tentang Keikutsertaan Pememeriksaan Inspeksi Visual Asam Asetat(IVA).}

Informasi yang efektif menjadi hal sangat penting, seperti halnya aliran darah, dan informasi memberi kontribusi yang dapat disamakan dengan rusaknya sistem peredaran darah dalam lebih dari satu organisasi. Informasi menjadi faktor terpenting dalam mendapatkan pengetahuan, merubah sikap dan mengaplikasikanya. Hal ini menunjukkan menunjukkan hasil uji perbandingan keikutsertaan pada saat pre-test di kelompok penyuluhan film dan leafleat dengan menggunakan uji mann withney (UTest) diperoleh $\mathrm{p}=0,778>0,05$ artinya tidak terdapat perbedaan sikap pada kelompok penyuluhan film dan leafleat tentang pemeriksaan Inspeksi Visual Asam Asetat pada wanita pasangan usia subur di wilayah kerja Puskesmas Pasarwajo pada saat sebelum dilakukan intervensi, sedangkan pada saat post-test diperoleh $\mathrm{p}=0,032<0,05$ artinya terdapat perbedaan sikap pada kelompok penyuluhan film dan leafleat tentang pemeriksaan Inspeksi Visual Asam Asetat pada wanita pasangan usia subur di wilayah .

Sikap merupakan reaksi atau respon yang masih tertutup dari seseorang terhadap suatu stimulus atau objek. Sikap secara nyata menunjukkan konotasi adanya kesesuaian reaksi tertutup yang dalam kehidupan sehari-hari merupakan reaksi yang bersifat emosional terhadap stimulus sosial. Newcomb, salah seorang ahli psikologis sosial, menyatakan bahwa sikap itu merupakan kesiapan atau kesediaan untuk bertindak (Priyoto, 2014). 
Sikap merupakan semacam kesiapan untuk bereaksi terhadap objek dengan cara-cara tertentu. Proses pembentukan sikap berlangsung secara bertahap, kemudian untuk bersikap diperoleh melalui proses belajar. Pengetahuan, pemikiran, niat, keyakinan, dan emosi memegang peranan pernting dalam penentuan sikap seseorang (Notoatmodjo S, 2010).

Perbedaan sikap yang ditunjukkan pada masingmasing kelompok dapat diakibatkan karena adanya perbedaan pengetahuan dan pemahaman terkait kanker sefiks dan deteksi dini.

Penelitian yang dilakukan oleh Mulyati (2015) di Bandung diperoleh hasil adanya peningkatan sikap ibu dalam pemeriksaan deteksi dini kanker serviks melalui media film. Penelitian serupa yang dilakukan oleh Wirawan (2014) menyimpulkan bahwa media audiovisual merupakan sumber informasi atau pengetahuan yang dapat ditangkap menggunakan indera pandang. Kurang lebih $75 \%$ sampai $87 \%$ informasi manusia yang diperoleh melalui indera pandang, $13 \%$ melalui indera pendengaran dan 12\% lainnya tersebar melalui indera yang lain.

\section{Perbedaan Penyuluhan Film dan Leafleat \\ Terhadap keikutsertaan pemeriksaan \\ Inspeksi Visual Asam Asetat ( IVA ).}

Kesehatan masyarakat merupakan kombinasi antara teori (ilmu) dan praktik (seni) yang bertujuan untuk mencegah penyakit, memperpanjang usia hidup, dan meningkatkan kesehatan penduduk (masyarakat), melalui upaya-upaya pengorgnisasian masyarakat (Notoatmodjo, 2007). Partisipasi masyarakat atau Peran Serta Masyarakat (PSM) di didang kesehatan sangat penting, agar individu, keluarga maupun masyarakat umum bertanggung jawab terhadap kesehatan diri, keluarga, ataupun kesehatan masyarakat lingkungannya.

Departemen Kesehatan merumuskan visinya, sebagai "Masyarakat yang mandiri untuk hidup sehat" dan misinya yaitu "Membuat masyarakat sehat", dengan strategi, yaitu menggerakkan dan memberdayakan masyarakat untuk hidup sehat, meningkatkan akses masyarakat terhadap pelayanan yang berkualitas, meningkatkan sistem surveilans, monitoring, dan informasi kesehatan, meningkatkan pembiayaan kesehatan (Depkes RI, 2006).

Dua bentuk media kelompok yang digunakan dalam keikutsertaan pemeriksaan Inspeksi Visual Asam Aseta yaitu Film dan Leaflet di mana Filmmerupakan gambaranya lebih kearah sasaran secara masal, sifatnya menghibur namun bernuansa edukatif dan Leaflet merupakan selembaran kertas yang berisi tulisan dengan kalimat-kalimat yang singkat, padat, mudah dimengerti dan gambargambar yang sederhana. Ada beberapa yang disajikan secara berlipat. Hasil menunjukkan hasil uji perbandingan keikutsertaan pada saat pre-test di kelompok penyuluhan film dan leafleat dengan menggunakan uji mann withney (U-Test) diperoleh $\mathrm{p}=1,000>0,05$ artinya tidak terdapat perbedaan keikutsertaan pada kelompok penyuluhan film dan leafleat tentang pemeriksaan Inspeksi Visual Asam Asetat pada wanita pasangan usia subur di wilayah kerja Puskesmas Pasarwajo pada saat sebelum dilakukan intervensi, sedangkan pada saat post-test diperoleh $\mathrm{p}=0,007<0,05$ artinya terdapat perbedaan keikutsertaan wanita pasangan usia subur dalam pemeriksaan Inspeksi Visual Asam Asetat pada kelompok penyuluhan film dan leafleat di wilayah kerja Puskesmas Pasar Wajo pada saat setelah dilakukan intervensi.

Penelitian ini sejalan denggan penilitian Amna Badra Krihnani (2011) Penggunaan media video pembelajaran terhadap pemahaman siswa pada mata pelajaran kitchenatau produktif khususnya pengolahan hidangan salad dapat dinilai efektif dalam proses pembelajaran pengolahan salad dibandingkan menggunakan metode konvensional. Dilihat dari hasil uji-t yang ada pada hipotesis penelitian ini, dengan membandingkan nilai rata-rata kelas kontrol dan nilai rata-rata kelas eksperimen.

\section{E. SIMPULAN DAN SARAN}

Dari penelitian ini diperoleh beberapa kesimpulan diantaranya:

1. Penyuluhan film dan leaflet berpengaruh terhadap pengetahuan tentang pemeriksaan Inspeksi Visual Asam Asetat (IVA) di Puskesmas Pasarwajo

2. Penyuluhan film dan leaflet berpengaruh terhadap sikap tentang pemeriksaan Inspeksi Visual Asam Asetat (IVA) di Puskesmas Pasarwajo

3. Penyuluhan film lebih efektif di banding leafleat dalam meningkatkan pengetahuan tentang pemeriksaan Inspeksi Visual Asam Asetat (IVA) di Puskesmas Pasarwajo

4. Penyuluhan film lebih efektif di banding leafleat dalam keikutsertaan pemeriksaan Inspeksi Visual Asam Asetat (IVA) di Puskesmas Pasarwajo

Adapun saran yang dapat peneliti sampaikan dari penelitian ini adalah bagi Pemerintah, khususnya Puskesmas Pasarwajo diharapkan dapat menerapkan promosi kesehatan dengan leaflet dan film dalam upaya deteksi dini kanker serviks, karena telah terbukti lebih efektif dalam meningkatkan pengetahuan dan perubahan perilaku partisipasi wanita. Dan selalu diadakan jadwal pemeriksaan IVA setiap 6 bulan sekali kepada wanita usia subur yang telah menikah.

\section{DAFTAR RUJUKAN}

[1] Kemenkes, R. 2016. Profil kesehatan Indonesia tahun 2016. Jakarta: Kementerian Kesehatan Republik Indonesia.

[2] Kementerian Kesehatan, R. 2017. Data dan Informasi Profil Kesehatan Indonesia 2016. Kementerian Kesehatan RI, 100. 
[3] Lubis, A. U. N., Mutiara, E. \& Ashar, T. 2017. Pengaruh Media Leaflet dan Film Terhadap Pengetahuan Tentang Kanker Serviks dan Partisipasi Wanita Dalam Deteksi Dini Kanker Serviks di Kampung Darek Kecamatan Padangsidempuan Selatan Tahun 2015. Jurnal Ilmiah PANNMED (Pharmacist, Analyst, Nurse, Nutrition, Midwivery, Environment, Dentist), 11, 158-162.

[4] Notoatmodjo S 2014. Ilmu Prilaku Kesehatan, Jakarta, PT Rineka Cipta.

[5] Saraswati, L. K. 2009. Pengaruh Promosi Kesehatan Terhadap Pengetahuan Tentang Kanker Serviks Dan Partisipasi Wanita Dalam Deteksi Dini Kanker Serviks (Di Mojosongo Rw 22 Surakarta). Universitas Sebelas Maret.

[6] Wati, L. 2017. Perbandingan Efektifitas Promosi Kesehatan Melalui Media Filem DAN Leaflet Terhadap Sikap dan Perilaku Detesi Dini Kanker Serviks Pada Wanita Usia Subur (WUS) Dengan Metode Inspesi VIisual Asam Asetat (IVA) Di Puskesmas Pal III Pontianak Kota. Jurnal ProNers, 3.

[7] Yusuf, A. M. 2016. Metode penelitian kuantitatif, kualitatif \& penelitian gabungan, Prenada Media.

\section{PROFIL PENULIS UTAMA}

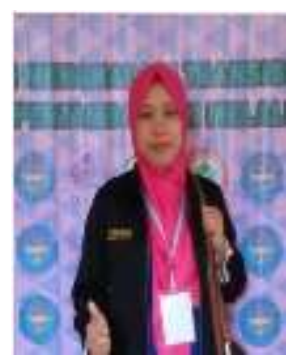

Eka Septiani, S.ST

DIII kebidanan pelita ibu Kendari (2010)

D IV Universitas Indonesia timur Makassar

(2014)

Alamat : jalan Lumba- Lumba Raha kab.

Muna 